\title{
Adsorption Characteristics of U (VI) in the Soil Horizons Near Uranium Tailing Impoundment Area
}

\author{
Sheng Yang, Xiaowen Zhang, Xiaoyan Wu, Mi Li, Lijiang Zhang, and Qianwen Huang
}

\begin{abstract}
Distribution of uranium (VI) between soil solids and solutions is a key parameter in assessing the risk to the biosphere of disposing uranium-rich waste products from uranium (U) ore mining and metallurgy. The different soil horizons have unequal physical and chemical properties and effect uranium adsorption and transformation on them. In this experiment, the effects of the soil horizons (eluvial horizon/E horizon, illuvial horizon/B horizon and parent material horizon/C horizon), particle size, contact times and temperature were discussed at $30 \mathrm{mg} / \mathrm{L}$ uranium solution. The maximum adsorption capacity of uranium for $\mathbf{E}$ and $\mathrm{B}$ horizon soils are 23.60 and $22.82 \mathrm{mg} / \mathrm{g}$, respectively at $45 \mathrm{~min}$, and for $\mathrm{C}$ horizon soil is $13.05 \mathrm{mg} / \mathrm{g}$ at $60 \mathrm{~min}$. The temperature and particle size shows different effects with different soil horizons. Uranium adsorption capacity increased by temperature from 15 to $25^{\circ} \mathrm{C}$ and had a slight down at 25 to $55^{\circ} \mathrm{C}$ for $\mathrm{E}$ and $\mathrm{B}$ horizon. But it increased by temperature from 15 to $55^{\circ} \mathrm{C}$ with $\mathrm{C}$ horizon. Uranium adsorption capacities are inversely proportion to grain-size scale for the three soil horizons. In addition, the results of XRF, and SEM on three soil horizons also confirmed that there are some differences among the soil profile on the compositional elements and particle size distribution. The experiment results may be helpful to predict the transformation of $U$ in soil and remediation program for tailing impoundment leachate.
\end{abstract}

\section{Index Terms - Uraniumm Soil horizons, adsorption.}

\section{INTRODUCTION}

The birth and development of nuclear energy represent a major step forward in the evolution of technologies. The mining and processing of uranium and thorium ore is one of the major activities to produce radioactive waste. Soil as a direct carrier of radioactive waste pollution, its adsorption behavior of $\mathrm{U}$ (VI) has been an important development direction in geochemistry [1], [2]. For example, Sarah et al. investigated the effect of $\mathrm{pH}$ on uranium sorption in downstream of Canadian $U$ mines. They found that adsorption of $\mathrm{U}(\mathrm{VI})$ to each sediment of the liquor was greatest at $\mathrm{pH} 6$ and 7 , and significantly reduced at $\mathrm{pH} 8$ [3]. Other studies showed that uranium sorption by some soils was heavily affected by not only the solution $\mathrm{pH}$ but also the temperature, the organic matter, the liquid to solid ratio, the soil particle size, coexistent ions and ionic strength [4], [5]. In addition, different soils had unequal physical and chemical properties, the adsorption and migration capacity of $\mathrm{U}(\mathrm{VI})$ is also vary widely.

Manuscript received June 12, 2018; revised October 12, 2018.

The authors are with the School of Environmental and Safety Engineering, University of South China, Hengyang, 421001, China (e- mail: shawn_zhang@sina.com).
It is worth mentioning that soil is formed by the weathering of rocks at the bedrock. The earth surface had various weathering degree of rock and biological activities, so the soil horizons in the same soil profiles also had huge differences of the physico-chemical components. These differences have a direct impact on the distribution of $\mathrm{U}(\mathrm{VI})$ in soil spatial structure. However, in simulations of safety evaluation of decommissioned uranium tailings reservoirs, soil is considered as a single homogeneous [6]. In fact, A horizon (A1 horizon / humus horizon, E horizon / eluvial horizon), B horizon (illuvial horizon), $\mathrm{C}$ horizon (parent material horizon) and the subsoil in the underlying horizon (G horizon / Gley horizon) is inequality to each other because of them had dissimilar physical properties and chemical compositions on the $\mathrm{U}(\mathrm{VI})$ adsorption capacity of different soil horizon, although they are in the same soil profile. In this experiment, the E horizon, B horizon and C horizon soil from the site that it nearby the Uranium tailings impoundment in southern China were used to study the effects of adsorption time, temperature and particle size of three soil horizons on unequal adsorption capacity of $\mathrm{U}(\mathrm{VI})$. The experimental results are helpful to study the spatial distribution of U (VI) in the soil profile of uranium tailings or other nuclear facilities and the adsorption mechanism of each soil horizon. It can provide a reference for the prediction of $\mathrm{U}(\mathrm{VI})$ sorption and migration in other tailing impoundment and for the assessment and disposal of low uranium radioactive waste.

\section{MATERIALS AND METHODS}

The E, B and C horizon soils used in the experiment were obtained from the Brown-Red soil profile based on the weathering of Purple-Shale nearby the uranium tailing impoundment. In the vertical section of the same place, the soil materials were taken from three types of the soil profiles respectively with eluvial horizon at $1.5 \mathrm{~m}$, illuvial horizon at $4.5 \mathrm{~m}$ and parent material horizon at $6 \mathrm{~m}$. According to "Standard for Soil Test Method" (GBT+50123-1999) and the BET analyzer, the stratification properties and primary elements of the soil horizons was measured and shown in table 1,2. Due to the biological activity of soil's surface and the atmospheric environment, the organic matter content and soil weathering degree on the surface humus horizon is the best. With the increase depth of soil profiles, the degree of soil horizon weathering as well as the content of elements and organic matter is different.

Take $0.1 \mathrm{~g}$ the soil samples to the $250 \mathrm{ml}$ conical flask with cover, add $100 \mathrm{ml}$ of Uranium(VI) solution $\left(30 \mathrm{mg} / \mathrm{L}^{-1}\right)$, and 
seal. The $\mathrm{pH}$ values of $\mathrm{U}$ (VI) stock solution were firstly adjusted to 6.2 depending on the $\mathrm{pH}$ value of the wastewater excreted by the tailing impoundment. Then, place in a constant temperature oscillator shock adsorption for $45 \mathrm{~min}$, standing, take $10 \mathrm{ml}$ of the supernatant to analyze $\mathrm{U}$ (VI) concentration.

TABLE I: THE PHYSICOCHEMICAL PROPERTIES OF THE SOILS

\begin{tabular}{|c|c|c|c|c|c|c|}
\hline Type & $\begin{array}{c}\text { Saturatio } \\
\text { Density / } \\
\mathrm{g} \cdot \mathrm{cm}^{3}\end{array}$ & $\begin{array}{c}\text { Dry } \\
\text { density } \\
/ \\
\mathrm{g} \cdot \mathrm{cm}^{3}\end{array}$ & $\begin{array}{c}\text { Water } \\
\text { content } \\
/ \%\end{array}$ & $\begin{array}{c}\mathrm{pH} \\
\text { value }\end{array}$ & $\begin{array}{l}\mathrm{BET} / \\
\mathrm{g} \cdot \mathrm{cm} \\
2\end{array}$ & $\begin{array}{c}\text { Organic } \\
\text { matter } \\
/ \mathrm{g} \cdot \mathrm{kg}\end{array}$ \\
\hline E Horizon & 1.56 & 1.25 & 19.87 & 4.01 & 40.33 & 36.51 \\
\hline B Horizon & 1.66 & 1.35 & 18.67 & 4.56 & 33.99 & 25.74 \\
\hline C Horizon & 1.71 & 1.50 & 12.28 & 7.22 & 17.56 & 2.10 \\
\hline
\end{tabular}

TABLE II: PRIMARY ELEMENTS OF THE SOILS

\begin{tabular}{|c|c|c|c|c|c|c|c|c|}
\hline $\begin{array}{c}\text { Type / } \\
\mathrm{mg} \cdot \mathrm{g}\end{array}$ & $\mathrm{Fe}$ & $\mathrm{Ca}$ & $\mathrm{Mn}$ & $\mathrm{K}$ & $S$ & $\mathrm{Ti}$ & $\mathrm{P}$ & $\mathrm{U}$ \\
\hline E Horizon & 69.46 & $\begin{array}{c}1.2 \\
0\end{array}$ & 0.21 & 27.60 & 3.30 & 7.56 & $\begin{array}{l}2.4 \\
9\end{array}$ & - \\
\hline B Horizon & 65.35 & $\begin{array}{c}1.2 \\
6\end{array}$ & 0.15 & 27.71 & 4.56 & 5.68 & $\begin{array}{c}3.3 \\
1\end{array}$ & - \\
\hline C Horizon & 48.51 & $\begin{array}{c}4.8 \\
1\end{array}$ & 1.01 & 32.74 & 2.86 & 4.04 & $\begin{array}{c}1.8 \\
5\end{array}$ & - \\
\hline
\end{tabular}

\section{RESULTS AND DISCUSSION}

\section{A. Adsorption Time}

From figure 1, it was found that the E and B horizon tend to be same features of uranium adsorption. When the adsorption time is at $0<t \leq 45 \mathrm{~min}$, the $\mathrm{U}$ (VI) removal efficiency increased rapidly with time. But the adsorption rate of $\mathrm{E}$ horizon and B horizon decreased at 45-60 min, and appeared desorption. After $60 \mathrm{~min}$, they are growth slowly. However, the $\mathrm{U}$ (VI) adsorption feature in the $\mathrm{C}$ horizon was similar to that of $\mathrm{E}$ and $\mathrm{B}$ horizons, but there are slightly dissimilar from them in equilibrium time. The adsorption of $U$ (VI) increased rapidly at $0-60 \mathrm{~min}$, then appeared desorption, after that, the adsorption amount of U (VI) increased slightly. Three kinds of soils appeared desorption process because that both physical adsorption and chemical reduction taken place U (VI) contacted with the soils [7]. In the early stage of adsorption, U (VI) diffused with the solvent in the soil, and the adsorption of $\mathrm{U}$ (VI) on the soil surface was mainly physical adsorption. At this time, the amount of adsorption increased rapidly. Flowed by the continuous adsorption of the soils, active groups and abundant inorganic colloids such as $\mathrm{Fe}(\mathrm{OH})_{3}$ complexes with uranyl ions to cause desorbing from the soil. After that, the spatial steric hindrance of the U (VI) dissociated from solution and the active sites for adsorption of soils are increased, and the adsorption amount of U (VI) gradually increased until equilibrium [7]. The saturated adsorption capacity of $\mathrm{U}$ (VI) in $\mathrm{E}, \mathrm{B}$ and $\mathrm{C}$ horizon were 23.6, 22.82 and $13.05 \mathrm{mg} / \mathrm{g}^{-1}$ and $\mathrm{E}>\mathrm{B}>\mathrm{C}$ horizon respectively. That can be explained by the difference of the main constituent elements, porosity and specific surface adsorption sites of each soil horizon.

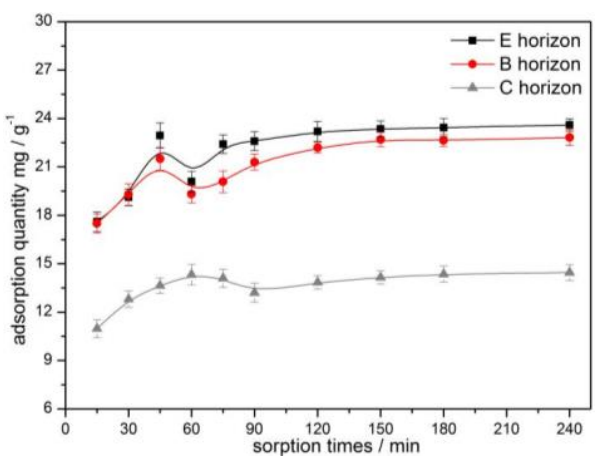

Fig. 1. The curve of $U(\mathrm{VI})$ adsorption with reaction time.

\section{B. Temperature}

The effects of temperature on $U$ adsorption on three horizon soils are shown in Fig. 2. It can be seen that the adsorption amount of $\mathrm{U}$ (VI) on the $\mathrm{C}$ horizon increases with temperature. However, the adsorption amount of $\mathrm{U}$ (VI) reached the maximum at $25^{\circ} \mathrm{C}$ for the $\mathrm{E}$ and $\mathrm{B}$ horizon, and then decreased with the temperature at $25^{\circ} \mathrm{C}$ to $55^{\circ} \mathrm{C}$. When the temperature reached $55^{\circ} \mathrm{C}$, they were in order as $\mathrm{E}>\mathrm{B}>$ $\mathrm{C}$ horizon. This result was similar to the experimental phenomenon of Feng et al [8]. Furthermore, the temperature raise can not only change the adsorption reaction rate but also affect the reaction process [9]. As shown in table 2, the E and $\mathrm{B}$ horizon's organic matter content are much higher than the $\mathrm{C}$ horizon, with the temperature increases, the organic functional groups (such as $-\mathrm{COOH},-\mathrm{OH}$, etc) gradually inactivated to lead adsorption capacity decreasing slowly. However, the rising of temperature made the activation energy of adsorption of soils minerals and inorganic colloid increased, as a result of that, the adsorption entropy and quantity also increased [10]. That made the U (VI) adsorption capacity on $\mathrm{C}$ horizon increased by temperature. Overall, the adsorption quantity of $\mathrm{E}$ and $\mathrm{B}$ horizon is still bigger than that of $\mathrm{C}$ horizon at $55^{\circ} \mathrm{C}$ for the inorganic colloid such as $\mathrm{Fe}-\mathrm{OH}$ in $\mathrm{E}$ and $\mathrm{B}$ horizon content is more than $\mathrm{C}$ horizon.

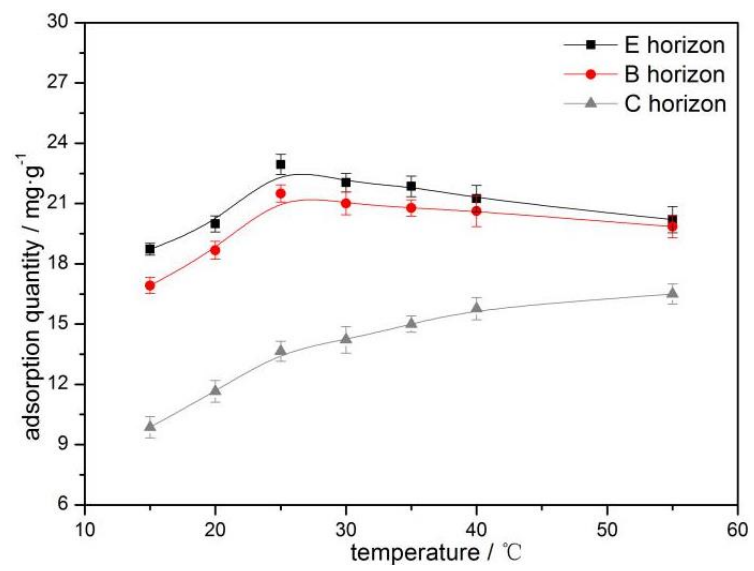

Fig. 2. The curve of $U(V I)$ adsorption with temperature.

\section{The Particle Size of the Soils}

Particle size was one of the crucial factors affecting the ad sorption rate. Figure 3 is the results of particle size of the soils on $\mathrm{U}$ adsorption with three horizon soils. It was showed that the removal efficiency and adsorption capacity of $\mathrm{U}$ (VI) increased with the decrease of particle size for the E, B and C 
horizon. When the particle size was less than 200 meshes, their adsorption capacities reached the maximum of 22.8 , 19.5 and $16 \mathrm{mg} / \mathrm{g}^{-1}$, respectively. Kritsananuwat et al [11] found that due to an increase in surface area per unit mass in small-grain sediments and negatively-charged surfaces of soil particles, the activity concentration of uranium in the soils tended to be enriched in the small-grained sediments and depleted in coarse-grained sediment. From the microcosmic configuration of three soil horizons (Fig. 4), The grain shape mostly appeare as globular and state loose for E horizon, and, appeare as coacervate with bigger grain size for B and C horizon for the weathering degree of $\mathrm{E}$ horizon is obviously better than $\mathrm{B}$ and $\mathrm{C}$ horizon.

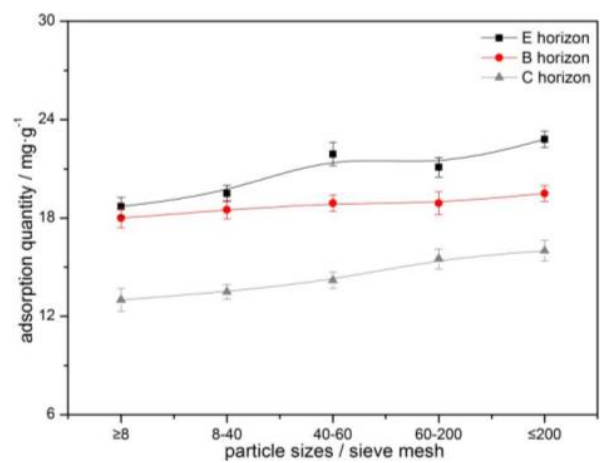

Fig. 3. The curve of $\mathrm{U}$ (VIVI) adsorption with different particle size of soil horizons.

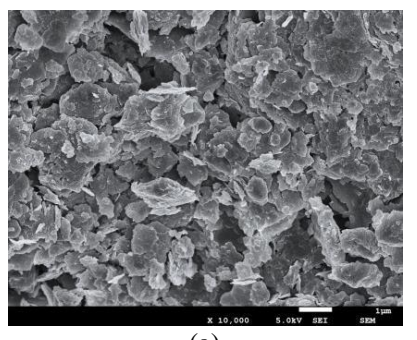

(a)

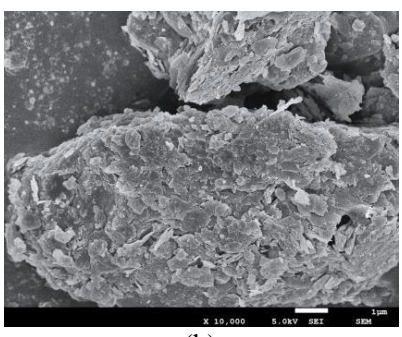

(b)

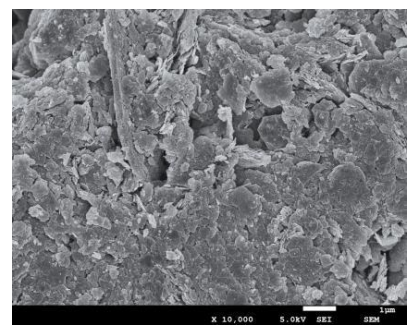

(c)

Fig. 4. Microcosmic configuration of the soil horizons: (a) E horizon soil; (b) B horizon soil; (c) C horizon soil.

\section{CONCLUSION}

a) The adsorption of $\mathrm{U}$ (VI) in the $\mathrm{E}$ and $\mathrm{B}$ horizon showed desorption phenomenon after the adsorption reached approximately $45 \mathrm{~min}$, but, it was at $1 \mathrm{~h}$ for $\mathrm{C}$ horizon. Three kinds of soils all appear desorption process because that both physical adsorption and chemical reduction take effect. The adsorption of $\mathrm{U}$ (VI) increased greatly at 15 to $25^{\circ} \mathrm{C}$, and reached the highest value at $25^{\circ} \mathrm{C}$ for $\mathrm{E}$ and $\mathrm{B}$ horizon. When the temperature was above 25 degrees, the adsorption capacity tended to decrease for $\mathrm{E}$ and $\mathrm{B}$ horizon soils. However, it kept increasing for $\mathrm{C}$ horizon from 15 to $55^{\circ} \mathrm{C}$. The uranium adsorption capacities are inversely proportion to grain-size scale of the three soil horizons since the smaller particle size it is the larger surface area has.

b) The different degree of weathering of each soil horizons led to the difference in physico-chemical properties such as density, water content, particle size, elemental composition and $\mathrm{pH}$ value. And, they are the main influencing factors to the U (VI) adsorption properties. There was an obviously difference in $\mathrm{U}$ (VI) adsorption capacity between $\mathrm{E} 、 \mathrm{~B}$ and $\mathrm{C}$ horizon. $\mathrm{U}$ (VI) is mostly adsorbed on the humus /eluvial horizon by surface humus or organic matter, thus the spatial distribution of uranium in the soil mainly accumulates on the surface, they are in order as $\mathrm{E}>\mathrm{B}>\mathrm{C}$ horizon. The uranium content decreases in the deeper soil horizon because of the preferentially adsorption of uranium in the $\mathrm{E}$ horizon at uranium tailings impoundment area (Uranium is generally enriched on the surface soil, with depth increases of the profile had lower content of Uranium), while the specific surface area of the topsoil, the content of elements such as Fe, $\mathrm{Ca}$ and $\mathrm{Mn}$, and, the physical and chemical properties are better than that of the $\mathrm{B}$ and $\mathrm{C}$ horizon.

c) The Experiments show that the soils of three soil horizons have different adsorption capacity for U (VI). So, the spatial distribution of uranium in the soil mainly accumulates on the surface when the soil is probably polluted by the tailings reservoir exudate. Contaminants may be transported to the environment by seepage and surface runoff (dissolved contaminants and suspended sediments). When the pollution accident occurs, we should mainly controlled uranium migration in the surface soil. During closure or decommissioning and remedial of tailings reservoir, attention should be paid to the pollution of surface soil, that is helpful for prediction of uranium migration and evaluating underground water quality.

\section{ACKNOWLEDGMENT}

This research was supported by the double first class construct program of USC (2017SYL05) and the master innovative items in 2017 of the School of Environmental and Safety Engineering, USC (2017YCXXM13).

\section{REFERENCES}

[1] Z. W. Niu, Q. H. Fan, W. H. Wang, J .Z. Xu, L. Chen, and W. S $\mathrm{Wu}$,"Effect of $\mathrm{pH}$, ionic strength and humic acid on the sorption of uranium(VI) to attapulgite," Appl Radiat Isotopes, vol. 67, pp.1582-1590, Mar 2009.

[2] R. Zuo, L. Liu, X.Y. Jiang, X. Guan, Y. G. Teng, F. Ding, J. Yang and J. S. Wang, "Factor influencing U(VI) adsorption onto soil from a candidate very low level radioactive waste disposal site in china," $\mathrm{Nucl}$ Technol Radiat, vol. 31, pp.268-276, Jul 2016

[3] S. E. Crawford, S. Lofts, and K. Liber, "The role of sediment properties and solution $\mathrm{pH}$ in the adsorption of uranium( VI) to freshwater sediments," Environ Pollut, vol. 220, pp. 873-88, Oct 2017

[4] A. J. Bednar, V. F. Medina, D. S. Ulmer-Scholle, B. A. Frey, B. L. Johnson, W. N. Brostoff, and S. L. Larson, "Effects of organic matter on the distribution of uranium in soil and plant matrices," Chemosphere, vol.70, pp. 237-47, Dec 2007 
[5] M. Gavrilescu, L. V. Pavel, and I. Cretescu, "Characterization and remediation of soils contaminated with uranium" J Hazard Mater, vol.163, pp.475-510, Apr 2009

[6] S. L. OuYang, S. Z. Li, and S. K. Zhou, "Numerical simulation on $\mathrm{U}(\mathrm{VI})$ in uranium tailing impoundment affected by acid rain," $A d v$ Mater, vol. 986-987, pp. 713-718, Jun 2014

[7] M. L. Bi, "U(VI) adsorption onto Beishan soil of Gansu," Lanzhou University, China, Jun 2016

[8] M. M. Feng, "Study about effect and mechanism of organic adsorbing uranium at an Uranium mine tailings reservoir," East China University of Technology, China. Jun 2016

[9] N. Fiol and I. Villaescusa,"Determination of sorbent point zero charge: usefulness in sorption studies," Environ Chem Letters, vol. 7, pp.79-84, Feb 2009

[10] Y. B. Pu, X. F. Yang, H. Zheng, D. S. Wang, Y. Su, and J. He, "Adsorption and desorption of thallium(I) on multiwalled carbon nanotubes," Chem Eng J, vol. 219, pp. 403-410, Mar 2013
[11] R. Kritsananuwat, S. K. Sahoo, M. Fukushi, K. Pangza and Chanyotha, "Radiological risk assessment of 238U, 232Th and 40K in Thailand coastal sediments at selected areas proposed for nuclear power plant sites," J Radioanalytical Nucl Chem, vol. 303, pp. 325-334, Jan 2015.

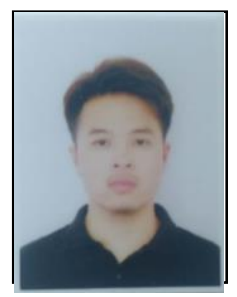

Sheng Yang was born in Hunan, PRC, on September 25 of 1993. He entered Hunan University of Science and Technology University in September of 2011 and belonged to the Department of architecture. He received the B.E. from Hunan University of Science and Technology University in 2016. He entered the School of Environmental and Safety Engineering, University of South China, in September 2016 as a master student. 